\title{
Sharing G. Evelyn Hutchinson's fabricational noise
}

\author{
Myrdene Anderson \\ Dept. of Sociology and Anthropology, Purdue University, \\ West Lafayette, Indiana 47907-1365, USA \\ e-mail: myanders@ecn.purdue.edu
}

\begin{abstract}
One of the seminal constructs in 20th-century biosemiotics is G. Evelyn Hutchinson's 'niche'. This notion opened up and unpacked cartesian space and time to recognize self-organizing roles in open, dynamical systems - in n-dimensional hyperspace. Perhaps equally valuable to biosemiotics is Hutchinson's inclusive approach to inquiry and his willingness to venture into abductive territory, which have reaped rewards for a range of disciplines beyond biology, from art to anthropology. Hutchinson assumed the fertility of inquiry flowing from open, far-fromequilibrium systems to be characterized by 'fabricational noise', following Seilacher, or 'order out of chaos', following Prigogine. Serendipitous 'noise' can self-organize into information at other levels, as does the 'noise' of Hutchinson's contributions themselves.
\end{abstract}

\section{An ecology of, by, and for, an ecologist}

Spectacular, seminal, searching minds - as that gracing George Evelyn Hutchinson (1903-1991) - do not emerge in every field, in every generation, in every culture, with any regularity, and when they do they defy every orderly principle. Of logic. Of comprehensibility. Of coherence. Such minds, and their works, emerge more willy-nilly, evoking evolutionary surprise in their observers and for their authors as well, rendering their occasional more linear, predictable, developmental contributions equally surprising, rather than suspenseful, as would otherwise be the case. 
The majority of researchers in any field are naturally apt to work in that appropriately-labelled discipline, and to communicate within its circumscribed discourse. Such usual, developmental discourse builds incrementally, linearly, and, at least in hindsight, predictably - corresponding to so-called gradual evolution, where difference is quantitative or one of degree. In contrast, the Hutchinsons in any discipline dart and wander around and beyond its boundaries. Intellectual peregrinations sometimes destabilize the received wisdom of an otherwise comfortable, orderly field. Periodically, though, collective understanding reorganizes with a surprising leap, in substance or direction - the analogue of punctuated evolution, a qualitative difference in kind. These metaphors of evolution and development in semiotic systems are drawn from Stanley Salthe (Salthe 1993, Salthe and Anderson 1989). I fancy Hutchinson would resonate with these metaphors as well.

The playful properties of Hutchinson license me, perhaps, to deal with him as subject and object in a strolling, trolling, manner. Or perhaps the situation is not one of license but rather an imperative. Either way, I take liberties. I take liberties with the slices of Hutchinson making up this salmagundi, and I take liberties with the strictures and structures of English style. To some extent, I address this document to Hutchinson as well. Like many of his essays, this one is in cant: oblique, lilting, intimate, inviting complementation and contest. Semiotician that he was, Hutchinson will find the beat and follow the intersecting spirals I trace in his oevre. In another life, I can make amends, and emendations.

\section{Ushering out, ushering in}

I was an usher, that's all. An usher at Hutchinson's memorial service. An ethnographer, too, you might say. That was at Yale's Battell Chapel, 19 October 1991, following Hutchinson's death in England on 17 May 1991. One hundred twenty days earlier, in early January 1991, I had watched sadly as Hutchinson left New Haven to visit, if not to remain in, his native England (Anderson 1998). Five years before his departure and death, he received the second Kyoto Prize in basic sciences. Eight years earlier, there had been a grand celebration of Hutchinson's 80th birthday at Yale's Peabody Museum. Twelve years earlier, on 24 October 1979, Hutchinson received the Franklin Medal of the Franklin Institute in Philadephia for Development of the Scientific Basis of Ecology. 
Closing his address to the Franklin Institute on the above occasion, he wrote:

Finally, since it has been said that nothing I say is wholly serious, I would like in this vein to express a hope that the honor you have done me is a tribute not only to partly forgotten and largely collaborative researches but also, in a minor way, to one or two more playful and ornamental exercises which I think may have given occasional pleasure to some of you. (Hutchinson 1979b: 4)

Eighty-eight years before his death, Hutchinson was born, 30 January 1903, in Cambridge, England. Hutchinson proceeded to study and be studied in Cambridge, Naples, Johannesburg, Tibet, numerous frothy ponds and illuminated manuscript archives, and Yale.

Contemplating Hutchinson today benefits from his, and our, willingness to wander, to trace the macramé of his mentation. Read aloud any of his work, and you will hear Hutchinson's voice. His experience and experiences imbue all of his writing with his personal touch and breath, and this is emphatically so with respect to his autobiographies: The Ecological Theater and the Evolutionary Play (1965) and The Kindly Fruits of the Earth: Recollections of an Embryo Ecologist (1979a).

\section{Strolling and trolling with and without G. Evelyn Hutchinson}

Like so many others of his generation, Hutchinson was precocious in early publication and prolific thereafter, and more and more eclectic with time. His bibliography published in Limnology and Oceanography 16(2) (March 1971) and 36(3) (May 1991) records Hutchinson's very first article, in 1918, titled 'A swimming grasshopper'. Hutchinson shared his research - on particular aquatic creatures (1968), populations and communities (1978a), species relationships (1954), bodies of water (1957), and chemical cycles (1948a) — with limnologists; but he also reported on science itself (1983), on biology generally (1948b), on taxonomy (1966), on larger ecological dynamics (1948c), on human evolution (1959a), on human culture (1955), on gender (1973a, 1973b), on art (1963, 1978b), on ethics (1948c), and on issues concerning global survival (1948c). By 1943, when his 'Marginalia' contributions were regularly featured in American Scientist, Hutchinson's wide-angled vision enlightened many across the 
broadest range of academic disciplines. He was generous in his critical reviews of cutting-edge books, and in his obituary essays commemorating departed colleagues. At the same time, Hutchinson shared his surviving circle of intellectual friends with others, making it possible for his students to read a variety of manuscripts in process and even to engage eminent scholar-scientists in correspondence. Hutchinson assumed that real scientists were scholars and vice-versa. Just as he was fascinated by phenomena at every scale and of every description, his collegial generosity knew no bounds.

What rendered Hutchinson's scholarly-scientific contributions particularly semiotic was his insatiable curiosity leading him to disregard or dispute traditional boundaries of research or of discourse, even in his own formulations. In the winter of his life, just before the spring of his death in 1991, he was asked about what singular problem we inherit at the end of the twentieth century; he instantly replied, 'insides and outsides' (Anderson 1998: 235). Among other things, this had relevance for the spatial and energetic parameters once pertaining to niche, even when referenced to n-dimensional hyperspace. Thereby, niche could connote a sophisticated space bounded by edges, beyond which there was no 'outside', enclosing an 'inside' distilled down to n-dimensional components. The elucidation of the concept of niche moved, in Hutchinson's mind, from analytic to synthetic, from extrinsically closed and concrete to intrinsically open and relational, from physical to semiotic, or, to borrow from Rosen (1991), from syntactic to semantic. The relational entails roles, in biology as well as in society, and roles construct emergent meanings rather than being the precipitates of extrinsic measurables.

While strolling and trolling himself, Hutchinson routinely turned every incident and observation along his path into meaningful relations with other phenomena. This he acknowledged in his lecture occasioned by the Kyoto Prize in 1986, which essay he titled 'Keep Walking' (Hutchinson 1986), quoting and crediting the advice he received from an indulgent editor. The gist of this essay was that ordinary evolutionary wandering folds into developmental trajectories, surprise fertilizes suspense, means can become ends, medium may be message, and chaos can sort itself into provisional order... and vice versa, Möbius-fashion. All of this Hutchinson subsumed as 'fabricational noise', a phrase he adopted from a narrower usage by Seilacher (1974). Fabricational noise also describes the self-organizational behavior in far-from-equilibrium systems (Prigogine and Stengers 
1979/1984), whether developmental or evolutionary, and is consonant with his student Slobodkin's characerization of evolution as 'existential poker' (Slobodkin 1968).

Hutchinson's adopted philosophy of 'keep walking', of strolling and trolling, recalls the equally magnificent metaphor deployed by Jakob von Uexküll in his, 'A stroll through the world of animals and men; a picture book of invisible worlds' (Uexküll 1957). Great minds, no doubt, stumble onto great metaphors as they stride.

\section{Relationships, perspectives, and invariance}

Hutchinson's approach to biosemiotics emphasized relationships (e.g., the roles eventually constituting 'niche') and holism (e.g., his compulsive inclusive integration of context with content). These inclinations cross-fertilized. Consequently, neither figure nor ground were fixed. About niche, Hutchinson ventured that critics may conclude it is 'compounded of equal parts of the obvious and the obscure' (1957: 416). And no interrogation of biological process could exclude the human interrogator together with his/her culture, language, and personality. Although bringing in gender in the marked hybrid possessive pronoun 'his/her' sounds inelegant, and consequently unHutchinsonian, he was truly fascinated by gender and how it played itself out in both society and science - witness his generous reviews of the works of his friend, Rebecca West (e.g., 1987), whose fourfooted cane he inherited and relied on for his strolling and trolling during the final five years of his life.

While known as an ecologist, in Hutchinson's practice of ecology there was no exclusion of ethology $(1957,1969)$. If we assume ecology to focus on the largely extrinsic material/energetic grounds relating some units of analysis, and ethology to consist in the overlapping and complementary behavioral roles, largely informatic, of and between some units of analysis (Anderson et al. 1984) - then it's clear that ecology and ethology are more than sibling disciplines; they are more like Siamese twins, but not just connected to each other, either. Semiotics entirely problematizes the traditional crutch of units of analysis.

Hutchinson's ecology, moreover, approached its subject matter from both the micro-experimental, descriptive level and the macrostatistical level seeking general laws, such as that obtaining between population density and body size. His strolls took him into realms of- 
ten considered incommensurable: the micro, the meta, the macro; the chemical, the biological, the cultural; the inductive, the deductive, the abductive; scale, rhythm, symmetry (1957).

Invariant among and between all of Hutchinson's contributions is the foregrounding of the provisionality of any and all units of analysis. Any units (molecule, gene, cell, organism, population, species, ecosystem-not to mention niche) are necessarily tentative or elusive, even as they are constituted vis-à-vis other formal units and within overarching temporal situations and spatial contexts. More persuasive units will not be spatial or energetic entities, but processual integrations also relating informatics and time, and/or any other dynamics which help consolidate our always interim understanding. While the significance of any description, analysis, or synthesis is at best provisional, given the infinite deferral inherrent in meaning-making, Hutchinson insisted that it was nonetheless imperative to be bold in the exercise of semiotic inquiry. Humans can and must build on and simultaneously challenge if not deconstruct accumulations of received wisdom packaged as knowledge.

\section{In pursuit of competition, cooperation, and creativity}

Biologists working with conventional models have taken process to be increasingly knowable, predictable, mappable. For example, complexity lends itself to be tamed by assumptions of closed-system competition through natural (or even artificial) selection. Hutchinson was among the earliest to find as suspect the overdetermined natural selection narratives of competition (1948b). He preferred to take into account obvious conditions of cooperation and allow for the opacity and transparency of both chance and necessity - and of ignorance.

One can speculate that Hutchinson's own personal habits of cooperation leaked into his analysis of various outcomes of biological process. Projection, after all, may be rampant in human cognition, and as such is certainly natural. In considering cooperation, leading to coevolution, biological process becomes more complex and nuanced-and more realistic and interesting.

Hutchinson could productively ratchet between the most improbable of sources and resources. Theorizing for him was an autotelic activity, resembling perhaps the self-rewarding compulsions of alloprimates afforded paints and canvas or musical instruments, who effortlessly go on to create designs in space and sound appealing to our sensibilities (1963: 107). 
For all his penchant for creativity, Hutchinson allowed some role for selection. Consider this: 'It is not necessary in any empirical science to keep an elaborate logicomathematical system always apparent, any more than it is necessary to keep a vacuum cleaner conspicuously in the middle of a room at all times. When a lot of irrelevant litter has accumulated the machine must be brought out, used, and then put away' (Hutchinson 1957: 416). This observation predates Kuhn (1962), and is much more graphic and satisfying!

As can be appreciated, Hutchinson was simultaneously humble and bold. Sometimes a well-meant scholar or student would venture to utter that Hutchinson was the 'father of ecology', whence Hutchinson - reflecting on his own fabricational noise - would usher out the admirer, and mutter, 'No, that would be Darwin'.

\section{References}

Anderson, Myrdene 1998. Apoptosis, the eradication of old ideas, and the persistence of weeds. Semiotica 120(3/4): 231-241.

Anderson, Myrdene; Deely, John; Krampen, Martin; Ransdell, Joseph; Sebeok, Thomas A. and Uexküll, Thure von 1984. A semiotic perspective on the sciences: Steps toward a new paradigm. Semiotica 44: 7-47.

Hutchinson, G. Evelyn 1948a. Circular causal systems in ecology. Annals of the New York Academy of Sciences 50, 221-246.

- 1948b. Biology. In Encyclopaedia Britannica. Reprint, 14 pages.

- 1948c. On living in the biosphere. The Scientific Monthly 67(6): 393-398.

- 1952. Methodology and value in the natural sciences in relation to certain religious concepts. The Journal of Religion 32(3): 175-187.

- 1954. Theoretical notes on oscillatory populations. The Journal of Wildlife Management 18(1): 107-109.

- 1955. Marginalia: Coda. American Scientist 43: 144-147.

- 1957. Concluding remarks. Cold Spring Harbor Symposium on Quantitative Biology 22: 415-427.

- 1959a. A speculative consideration of certain possible forms of sexual selection in man. American Naturalist 93(869): 81-91.

- 1959b. Homage to Santa Rosalia, or, Why are there so many kinds of animals? American Naturalist 93: 145-159.

- 1963. The naturalist as an art critic. Proceedings of the Academy of Natural Sciences of Philadelphia 115(5): 99-111.

- 1965. The Ecological Theater and the Evolutionary Play. New Haven: Yale University Press.

- 1966. The sensory aspects of taxonomy, pleiotropism, and the kinds of manifest evolution. American Naturalist 100(915): 533-540. 
— 1968. When are species necessary? In: Lewontin, Richard C. (ed.), Population Biology and Evolution. Syracuse: Syracuse University Press, 177186.

- 1969. Ecological biology in relation to the maintenance and improvement of the human environment. In: Applied Science and Technological Progress: A Report to the Committee on Science and Astronautics, U.S. House of Representatives, by the National Academy of Sciences, 171-184.

- 1973a. Population and behavior. In: Williams, Preston N. (ed.), Proceedings of a Symposium on the Identity and Dignity of Man. Cambridge, Massachusetts: Schenkman Publishing Company, 120-123.

- 1973b. Problems of population control. In: Williams, Preston N. (ed.), Proceedings of a Symposium on the Identity and Dignity of Man. Cambridge, Massachusetts: Schenkman Publishing Company, 151-152.

- 1978a. An Introduction to Population Ecology. New Haven: Yale University Press.

- 1978b. Zoological iconography in the West after A.D. 1200. American Scientist 66(6): 675-684.

- 1979a. The Kindly Fruits of the Earth: Recollections of an Embryo Ecologist. New Haven: Yale University Press.

- 1979b. Untitled address to the Franklin Institute, Philadelphia, 24 October 1979, upon receipt of the Franklin Medal, for Development of the Scientific Basis of Ecology. Stencil manuscript.

- 1983. Marginalia: What is science for? American Scientist 71(6): 639-644.

- 1986. Keep walking. [The lecture upon receipt of the Kyoto Prize 1986 (Basic Sciences) awarded to G. Evelyn Hutchinson.] Physiological Ecology of Japan 24: 81-86.

- 1987. Rebecca West. The Yale Review 76: 203-205.

Kuhn, Thomas S. 1962. The Structure of Scientific Revolutions. Chicago: University of Chicago Press.

Limnology and Oceanography 1971, 1991. G. Evelyn Hutchinson Celebratory Issue. [Limnology and Oceanography 16(2): 157-179, 473-477 (March 1971) bound as reprint with Limnology and Oceanography 36(3) (May 1991).]

Prigogine, Ilya; Stengers, Isabelle 1979/1984. Order Out of Chaos. Trans. from the French. New York: Basic Books.

Rosen, Robert 1991. Life Itself: A Comprehensive Inquiry Into the Nature, Origin, and Fabrication of Life. New York: Columbia University Press.

Salthe, Stanley N. 1993. Development and Evolution: Complexity and Change in Biology. Cambridge: MIT Press.

Salthe, Stanley N.; Anderson, Myrdene 1989. Modeling self-organization. In: Prewitt, Terry J.; Deely, John and Haworth, Karen (eds.), Semiotics 1988. Lanham: University Press of America, 14-29.

Seilacher, Adolf 1974. Fabricational noise in adaptive morphology. Systematic Zoology 22: 451-465. 
Slobodkin, L. B. 1968. Toward a predictive theory of evolution. In: Lewontin, Richard C. (ed.), Population Biology and Evolution. Syracuse: Syracuse University Press, 187-205.

Uexküll, Jakob von 1957. A stroll through the world of animals and men; a picture book of invisible worlds. In: Schiller, Claire H. (ed.), Instinctive Behavior: The Development of a Modern Concept. New York: International Universities Press, Inc., 5-80.

\section{Разделяя “фабрикационный шум" Г. Ив.лина Хатчинсона}

Один из продуктивных конструктов биосемиотики 20 в. — “ниша" Г. Ивлина Хатчинсона. Это понятие раскрыло картезианское пространство и время, что повлекло за собой признание самоорганизации в открытых динамических системах, в n-мерном гиперпространстве. Возможно, не менее ценен для биосемиотики инклюзивный подход Хатчинсона к исследованию и его готовность покорять новые территории, что вознаграждается во многих дисциплинах за пределами биологии, от искусствоведения до антропологии. Хатчинсон предполагал, что плодотворность исследования проистекает из открытых, неравновесных систем, характеризуюшихся "фабрикационным шумом" по Зейлахеру, или "порядком из хаоса", по Пригожину. Открывательский "шум" может самоорганизовываться в информацию на других уровнях, так же как “шум” открытий самого Хатчинсона.

\section{Osasaamine G. Evelyn Hutchinson'i "valmistusmürast"}

Üks 20. sajandi biosemiootika produktiivsetest konstruktsioonidest on G. Evelyn Hutchinson'i “nišš". See mõiste avas kartesiaanliku ruumi ja aja, mis tõi endaga kaasa enesereguleerimismehhanismi tunnistamise avatud dünaamilistes süsteemides, n-mõõtmelises hüperruumis. Võimalik, et mitte vähem tähtis biosemiootika jaoks on Hutchinsoni inklusiivne lähenemine uurimistööle ja tema valmidus hõlvata uusi territooriume, mis on andnud tänuväärseid võrseid paljudel bioloogiast väljapoole jäävatel aladel kunstiteadusest antropoloogiani. Hutchinson arvas, et uurimuse tulemuslikkus tuleneb avatud, tasakaalustamata süsteemidest, mida iseloomustab "valmistusmüra" (Seilacheri termin) või "kord kaosest" (Prigogine). Avastuslik "müra" võib iseorganiseeruda informatsiooniks teistel tasanditel, samuti nagu Hutchinsoni enese avastuste "müra". 